\title{
21. GEOLOGIC BACKGROUND OF THE RED SEA ${ }^{1}$
}

\author{
Robert G. Coleman, U. S. Geological Survey, Menlo Park, California
}

\section{INTRODUCTION}

New concepts related to the mobility of the earth's crust have focused attention on the Red Sea area. Anyone familiar with the geographic outline of western Arabia and northeast Africa is struck by the apparent jig-saw fit that appears possible in closing the Red Sea. Indeed, the modern paradigm of plate tectonics would have the Arabian Peninsula drifting away from the African continent. Considerable research has been done in the Red Sea area, both from the standpoint of demonstrating plate tectonics and in exploration for oil and metals. The purpose of this paper is to consolidate some of the geologic and geophysical information on a generalized geologic map at the scale of 1:2,000,000 (Plate 1).

Even though all original sources were not available to the author, it is felt that the present compilation will provide a basis for guiding further work. All map compilations of this sort become anachronistic upon printing and the author would, therefore, welcome all new information or constructive criticism. Whiteman (1970) has made an appeal for the construction of a Red Sea structural map, and for good reasons. This map, however, is not considered as a substitute and it has many of the built-in problems discussed by Whiteman.

\section{PHYSIOGRAPHY}

The Red Sea occupies an elongate depression over 2000 $\mathrm{km}$ long. In the northern part, shorelines are only $180 \mathrm{~km}$ apart; southward, the gap widens to $360 \mathrm{~km}$. At the south end the flat-lying, coral-topped Farasan and Dahlak Archipelagoes rise slightly more than 60 meters above sea level and are part of a shallow shelf extending nearly to the center of the Red Sea (MacFadyen, 1930). The southern part of the Red Sea narrows $(28 \mathrm{~km})$ to the straits of Bab el-Mandeb, where it connects with the Gulf of Aden. North of the straits a series of volcanic islands occupies the medial part of the Red Sea (MacFadyen, 1932). The most recent bathymetric chart of the Red Sea (Laughton, 1970) reveals a very distinct main trough extending northward from the Zebayir Islands to the southern tip of the Sinai Peninsula. The main trough is cut by an axial trough varying from 30 $\mathrm{km}$ in width near $20^{\circ} \mathrm{N}$ and narrowing southward where it may be 5 to $14 \mathrm{~km}$ wide (Plate 1). Selected topographic cross-sections reveal steep-sided walls in the axial trough and a very irregular bottom topography. A line connecting the deepest parts of the axial trough reveals sharp changes in direction, with apparent offsets. High temperature brine pools and hydrothermal sediments are present within the axial trough. The bottom topography is shallow and flat on

${ }^{1}$ Publication authorized by the Director, U. S. Geological Survey. the Red Sea shelf. South of Jidda, Saudi Arabia, the shelf merges imperceptibly with the coastal plain; north of Jidda it is narrower and interrupted by rather sharp topographic breaks. The coastal plains broaden south of Jidda and widen to $50 \mathrm{~km}$ in Yemen and Saudi Arabia. Volcanic flows cover parts of the plain in Arabia and Ethiopia. North of latitude $22^{\circ} \mathrm{N}$ the coastal plains tend to be narrower, with terraces well above the present shoreline. The general aspect is one of shoreline emergence to the north and of submergence to the south.

Landward from the littoral zone and coastal plain, the topography varies considerably and is best described in segments. A magnificent erosional escarpment extends unbroken southward from Taif in Saudi Arabia to Taizz in Yemen, forming the crest of the tilted Arabian block. The crest follows an extremely irregular erosional pattern that is subparallel to the coastline, extending inland as far as 120 $\mathrm{km}$ in some places and less than $50 \mathrm{~km}$ in others. In Yemen, altitudes of over 3700 meters have been measured, and in Saudi Arabia the scarp crest averages more than 2000 meters (U.S. Geological Survey, 1963). No major normal faults parallel to the Red Sea or to the escarpment have been recognized between the coastal plain and the crest. In Ethiopia, a similar scarp bounds the coastal plain on the west, reaching altitudes of over 3000 meters. Geologic evidence here shows a close relationship between faulting and the scarp (Mohr, 1962). At Massawa, the scarp turns southward and leaves the Red Sea trend, connecting with the East African rift system. South of Massawa, broadening of the East African rift system has produced the magnificent Afar Depression. Extensive volcanism and block faulting in the Afar Depression have produced an incredible mixture of interior basins and volcanic landscape.

The coastal plains in Sudan and southern Egypt are narrow and not bordered by scarps. Instead, the lower slopes merge seaward as interdigitating fans and pediments broken by outliers of older rocks (Whiteman, 1971). A similar situation exists along the coastal plain on the east side of the Red Sea at these latitudes. The northern end of the Red Sea bifurcates into the Gulf of Suez and the Gulf of Aqaba, the former controlled primarily by normal faulting, the latter by wrench faults. The narrow coastal plains here climb directly into fault-bounded blocks of basement rock less than 5 to $10 \mathrm{~km}$ from the shoreline.

\section{GEOLOGY}

\section{Stratigraphic Record}

Paleogeographic reconstructions (Swartz and Arden, 1960; Said, 1962; Mohr, 1962; Brown, 1972) for the Mesozoic show Jurassic seas spreading northward to Massawa and Jizan, and the shoreline trending directly across the Red Sea at latitude $17^{\circ} \mathrm{N}$. To the northwest the 
Jurassic shoreline crosses the Sinai Peninsula trending east-west at about latitude $29^{\circ} \mathrm{N}$. By the end of the Cretaceous period the Tethyan Sea reached southward to approximately latitude $21^{\circ} \mathrm{N}$ (Whiteman, 1968, 1971; Karpoff, 1957; Carella and Scarpa, 1962). In the south, regressive Cretaceous marine facies are present in Ethiopia and southern Yemen extending northward only to latitude $13^{\circ} \mathrm{N}$. The marine sedimentary record for the Mesozoic provides no strong evidence that the Red Sea depression existed during this time. Indirect evidence of tectonic activity during Mesozoic times in and around the Red Sea is generally lacking. However, interlayering of basaltic rocks with Cretaceous sedimentary rocks signals the beginning of emplacement of the thick trap rock sequences in Yemen (Guekens, 1966).

The early Tertiary sedimentary record in the Red Sea area is incomplete and has been the subject of debate. It is generally agreed that during Eocene time transgressive marine deposits developed in the northern Sinai and Egypt and that Eocene rocks may occur as far south as Maghersum Island, Sudan (Said, 1962; Whiteman, 1968; Sestini, 1965; Carella and Scarpa, 1962). Shorelines of early and middle Eocene age are shøwn to extend across the southern end of the Red Sea, and by the end of the Eocene epoch the horn of Africa had completely emerged (Mohr, 1962). Oligocene sediments have not been positively identified along most of the Red Sea coastal plains; however, deposition of the Red Series in the Danakil Depression is considered to have begun in the late Oligocene (Bannert et al., 1970; Barberi et al., 1972). Oligocene sediments were encountered in exploratory drilling for iron ore in Wadi Fatima east of Jeddah (Shanti, 1966). Oligocene and Miocene marine sediments are found on the south coast of the Arabian Peninsula (Beydoun, 1964). Deep wells along the western margins of the Red Sea have penetrated shale containing Oligocene fossils and interlayered basalt that gives Oligocene radiometric ages (Whiteman, 1968). Further deep drilling will resolve the question of whether Oligocene sediments underlie the Red Sea depression. Separate great uplifts on either side of the Red Sea during Oligocene time were accompanied by outpourings of alkaline basalts that now form thick trap series as high plateaus behind the Arabian and Ethiopian scarps. The paucity of Oligocene marine sediments in and around the Red Sea depression has prompted some geologists to suggest that during the Oligocene the Red Sea trend occupied the crest of a large Afro-Arabian dome or domes (Gass, 1970; Swartz and Arden, 1960).

Miocene sediments have been described along the coastal plains of the Red Sea from the Gulf of Suez to latitude $14^{\circ} \mathrm{N}$ (Said, 1962; Heybroek, 1965, Brown, 1970). Numerous deep exploratory wells have penetrated great thicknesses of Miocene clastics (2-3 km) and evaporites $(3-4 \mathrm{~km})$ without reaching basement rocks (Ahmed, 1972). This new geologic information, combined with that obtained on Leg 23, Deep Sea Drilling Project, demonstrates that the Red Sea depression received marginal clastic sediments interfingering with evaporites during Miocene times. The Miocene marine invasion is considered to have come from the Mediterranean rather than from the Indian Ocean (Montanaro, 1941). During the Miocene, volcanic activity continued in the Afar Depression and in western Saudi Arabia. As the Red Sea depression continued to subside, uplift continued in the Arabian-Yemen block and the Ethiopian segment.

At the beginning of the Pliocene, marine oozes and marginal clastics began to be deposited on the evaporite sequence, signalling a drastic change in the sedimentary record. The Pliocene marine invasion is considered to have come from the Indian Ocean rather than the Mediterranean because the latter was separated from the Red Sea during the early Pliocene by uplift of the Isthmus of Suez (Swartz and Arden, 1960). The lack of Miocene salt deposits in the axial trough of the Red Sea has been confirmed by drilling on Leg 23, Deep Sea Drilling Project. In the axial trough a thin veneer of sediments overlies basalt that is considered to have been extruded into the axial trough (Gass, 1970). Continuous seismic reflection profiles made across the shelf of the Red Sea confirm the presence of a strong reflector at depths up to 500 meters, which is now considered to represent the top of the evaporite section (Phillips and Ross, 1970; Ross et al., 1972). Assuming that the salt once extended across the axial trough, the seismic profiles reveal a separation of 48 to $74 \mathrm{~km}$ across the main trough. Rates of deposition of Pliocene and Pleistocene sediments in the southern part of the Red Sea were distinctly higher than those observed at the latitude of Jidda, indicating continued uplift and erosion along the southern margins of the Red Sea (Ross et al., 1972). Within the Afar Depression a thick section ( $975 \mathrm{~m}$ ) of evaporites overlies the Red Series (Holwerda and Hutchinson, 1968). These evaporites are considered to be Pleistocene in age and are probably evidence of intermittent connections with the Red Sea through the Zula Gulf (Hutchinson and Engels, 1970).

All along the present shorelines there are recent coral reef deposits of limestone, some of which are as much as 300 meters thick. Along the east margin near Jizan, these deposits are rapidly buried by the clastic debris brought into the littoral zone from the high erosional scarps.

\section{Structure}

The divergent trends of the Red Sea depression and adjacent Precambrian basement clearly indicate that the Red Sea depression is not related to these early structures (Picard, 1970; Schürmann, 1966; Brown and Jackson, 1960). Recent structural maps (Brown, 1972; Choubert, 1968) further amplify the discordance and show that Paleozoic to Paleogene sediments and related structures cannot be part of the Red Sea evolution.

Uplift in Ethiopia and Arabia took place on an immense scale immediately after the late Eocene regression (Mohr, 1962). The Hail Arch, an early Paleozoic northtrending headland in the Precambrian basement of the Arabian shield was deformed during pre-Permian times and during late Cretaceous time was folded parallel to its N-S axis (Greenwood, 1972). Fractures that developed as part of the uplift provided feeder fissures for the Oligocene Trap Series in Ethiopia and Arabia. A monoclinal flexure developed along the eastern margin of the Red Sea as the Yemen-Hail arches formed. East of Jizan along the hinge lines of the monoclinal warp, zones of stretched, fractured rock were invaded by tholeiitic magma, forming local differentiated 
layered gabbros, granophyres, and diabase dike swarms ranging in age from 20 to 25 m.y. (Coleman and Brown, 1971). Uplift and arching in Ethiopia coincided with the intrusion of granite and rhyolite (22-25 m.y.) marginal to the Afar Depression (Barberi et al., 1972). In Ethiopia, continued uplift duirng the Oligocene and Miocene produced a complex pattern of major faults that gave rise to the downfaulted Afar.Depression, the Danakil horst, and the highlands west of the depression (Tazieff et al., 1972). Deposition of the Red Series, confined to the Afar Depression, began in the late Oligocene and marked the warping of the depression (Bannert et al., 1970; Barberi et al., 1972). The normal faults bounding the depression are still active (Gouin, 1970). During Oligocene and Miocene time, uplift was sustained in the Yemen-Hail arches with continued monoclinal flexuring and gentle downwarping of the coastal plain. The thick Miocene clastic sections discovered in deep wells along the coastal plains were deposited unconformably on older downwarped units and demonstrate rapid erosion of the Yemen-Hail and Ethiopian arches (Gillmann, 1968). Steep dips of Jurassic and early Miocene sedimentary rocks towards the Red Sea axis along the monocline indicate downwarping of the Red Sea depression (Coleman and Brown, 1971; Gass and Gibson, 1969). Major normal faults have not been found along the eastern margin of the Red Sea, even though they are shown on numerous generalized maps (see, for instance, Mohr, 1962, p. 160; Picard, 1970; Holmes, 1965). Whiteman's (1968, p. 235) comments on a presumably fault-bounded Red Sea are appropriate. "It is not possible here to give all the details relating to the nature of the bounding escarpments but analysis reveals that many of the faults shown on general maps do not exist on the ground and have, in fact, been put in on the assumption that most of the escarpments are of fault origin. It is indeed curious that almost every map of the Red Sea Depression showing faults shows a different pattern." Important to this argument is the recognition that the contacts between the Mesozoic and Tertiary sediments and the Precambrian basement are unconformities, and that the sediments dip steeply toward the axis of the depression. Perhaps some geologists hold to the veiw that the Red Sea is bounded by faults because the Suez and Aqaba grabens and the Afar Depression are all well-documented fault-bounded structures. The matching shorelines of the northern Red Sea along with the subparallel southern erosional scarps in the Arabian Peninsula and Ethiopia give quasitectonic evidence that permits this interpretation. Minor normal faults are associated with the monoclinal flexures along the Red Sea, and continued exploratory drilling may reveal major normal faults concealed by the thick Miocene evaporite-clastic deposits (Lowell and Genik, 1972). However, the Oligocene and Miocene development of the Red Sea depression deduced from the stratigraphic and structural record indicates that the northwest-southeast trending depression developed as a trough between the Arabian and African swells, rather than as a downfaulted block (Brown and Coleman, 1972).

Mobility of the Miocene evaporites is indicated by the numerous salt domes developed in the marginal parts of the Red Sea south of latitude $18^{\circ} \mathrm{N}$ (Brown, 1972). Salt domes may have begun to develop during the Pliocene and may be currently forming. Present-day subsurface salt flowage has been recorded at depths greater than 3000 meters (Frazier, 1970). At bottom-hole temperatures above $200^{\circ} \mathrm{C}$, and under the pressure of thick overburdens, salt will act very nearly like soft butter. Salt could easily flow into the axial trough, and the irregular topography at latitude $16^{\circ} 40^{\prime} \mathrm{N}$ suggests that this may well have happened. Strong deformation of the top surface of the evaporites, as deduced from seismic profiles, clearly indicates salt flowage (Phillips and Ross, 1970).

Formation of the axial trough at the beginning of the Pliocene appears to have been related to a major rift, a marked departure from the Oligocene and Miocene development of the Red Sea depression. The physiography of the trough, a steep-walled depression with a floor of new basaltic crust, bears out the similarity to other active mid-ocean spreading centers. Concentration of seismic epicenters within the axial trough and alignment of active volcanoes along the trough axis also indicate present-day rifting. Solution of first motions on recent epicenters in the axial trough indicates movement along northeast-southwesttrending transform faults (Fairhead and Girdler, 1970; McKenzie et al., 1970). These first-motion solutions, combined with geologic studies, have shown that current left-lateral shear along the Dead Sea rift fits in with the general northeast movement of the Arabian plate away from Africa. In summary, synthesis of the present structural knowledge on the evolution of the Red Sea indicates at least two stages of development-pre-Miocene downwarping with crustal thinning and post-Miocene rifting.

\section{Volcanology}

Distribution of Tertiary volcanic rocks provides further clues as to the origin of the Red Sea depression. One of the largest areas of alkaline basalts in the world is centered over Ethiopia, Yemen, and western Saudi Arabia. Eruption of these lavas accompanied the development of the Ethiopian and Arabian swells, probably starting in early Eocene in Yemen and culminating in the Oligocene in both Ethiopia and Arabia (Baker et al. 1972). The Ethiopian Trap Series near Asmara has been dated as 36 m.y., and the Sirat plateau basalts of Arabia have been bracketed between 25 to 29 m.y. (Brown, 1970). These flood basalts are predominately alkaline olivine basalt, with some interbedded silicic lavas, agglomerates, and pyroclastics (Baker et al., 1972). In the Ethiopian plateau the Trap Series reaches a thickness of 3500 meters; in Yemen, 1000 meters. The Yemen Trap Series extends northward into Saudi Arabia, where these rocks are called the Sirat plateau basalts and thin to about 400 meters. No evidence has been discovered that shows whether the Ethiopian and Arabian Peninsula plateau basalts were coextensive across the southern part of the Red Sea; however, deep drilling there would resolve this question. The Yemen Trap Series forms an anticlinal swell, with the western margin dipping under the coastal plain (Brown, 1971). On the Danakil horst, pre-Miocene basalts cover Mesozoic deposits and appear to dip toward the Red Sea axis, but these basalts may not be equivalent to the Eocene and Oligocene Trap Series. In both Ethiopia and Arabia the basal flows have been 
extruded upon an extensive laterite that is considered to be Portlandian to Eocene in age (Mohr, 1962). The chemical and petrographic continuity of the Yemen and Ethiopian Trap Series has been demonstrated by Mohr (1971) and recent work by Coleman and Brown (1971) on the Sirat plateau basalts extends the area of this great effusion of alkali olivine basalts. Northward on both sides of the Red Sea depression there are no extensive areas of trap rock of this age. Tromp (1950) reports minor but widespread Oligocene basalt flows within the marine sediments of eastern Egypt; however, no petrographic details are available.

In Miocene time ( 22 m.y.), differentiated layered gabbros and tholeiitic dike swarms invaded the hinge line of monoclinal downwarps along the south Arabian coast (Coleman and Brown, 1971). East of Jizan a canoe-shaped layered gabbro approximately 300 meters thick is associated with diabase dikes cutting Jurassic sandstones. Dike swarms several hundred meters across trend parallel to the Red Sea in this area, and linear magnetic anomalies associated with sporadic dike outcrops have been traced as far north as Jidda (Brown, 1971). Within the Afar Depression, mainly along its margins, small granitic intrusive and silicic volcanic rocks (22-25 m.y.) are considered to be related to the downwarping and marginal faulting that created the Afar Depression (Barberi et al., 1972).

As the Miocene evaporite and clastic deposits accumulated in the Red Sea depression, great volumes of alkali olivine lavas erupted along the crest of the Hail Arch north of Jidda. These flows are generally less than 50 meters thick; nonetheless, they spread over vast areas, some even extending westward over the coastal plain. The bulk of these flows lies approximately 150 to $200 \mathrm{~km}$ inland from the Red Sea, and north-south alignment of vents on the flows parallels the Hail Arch, an early Paleozoic headland of Precambrian crystalline rocks (Greenwood, 1972). Contemporaneous with these inland flows are other alkali olivine basalt extrusions along the same north-south trend situated between Amman in Jordan and Turayf in northern Saudi Arabia, more than $250 \mathrm{~km}$ from the Red Sea. Exploratory deep drilling in the Miocene evaporite and clastic section has penetrated interlayered basalts in the southern Red Sea (Lowell and Genik, 1972), and interlayered Miocene basalts are reported to the Red Series of the Afar Depression (Bannert et al., 1970), indicating the possibility of discontinuous rifting in the Red Sea depression during Miocene time.

As the axial rift in the Red Sea began to form, sometime early in the Pliocene ( $\sim 5$ m.y.), subalkaline oceanic tholeiites began filling the axial trough and numerous submarine volcanoes contributed pryoclastic rocks and lava (Chase, 1969). While this was happening, many small alkaline olivine basalt eruptive centers developed along the hinge line of the flexure zone of the eastern margin of the Red Sea south of latitude $19^{\circ} \mathrm{N}$. Mantle xenoliths common to these basaltic eruptions indicate a source much different from that of the rift basalts filling the axial trough some $170 \mathrm{~km}$ to the west. Additional widespread alkaline olivine basalts were erupted along the crest of the Yemen and Hail Arches from Yemen northwards to Tabuk in Saudi Arabia.
Mantle xenoliths have also been reported from these rocks. This volcanic activity has continued until the present, with historical eruptions reported near Medina, Saudi Arabia, and in Yemen.

Within the Afar Depression, the Pliocene rifting of the axial part of the Red Sea was accompanied by a great outpouring of flood basalts-the Stratoid Series (Barberi et al., 1972). This volcanism is considered to have extended from the late Miocene to Quaternary and is represented by transitional basalts and peralkaline silicic rocks (Barberi et al., 1972). Continuing up to the present, volcanism in the axial trough of the Afar Depression produces what are considered to be transitional basalts with affinities toward subalkaline oceanic basalts and including some silicic welded ash-flow tuffs and lavas. Marginal vents from which silicic rocks have erupted remain active today. In the Red Sea depression, within the straits of Bab el-Mandeb and northwards to Jabal Tair, Holocene volcanic islands have developed along the axial rift. Rock types progress from oceanic tholeiite at Jabal Tair southward to alkali basalt, trachybasalts, and trachyandesites within the Zukur-Hanish Islands (Gass et al., 1965). Basaltic and peralkaline eruptive centers extend eastward along the south coast of Aden. Individual small submarine peaks within the axial trough are also considered to be extinct volcanoes.

\section{Geophysics}

Many geophysicists have worked in the Red Sea area, but mostly in conjunction with oceanographic expeditions rather than land surveys. Political problems have prevented a complete magnetic or gravity survey of the whole region. Most geophysical interpretations are therefore made from local surveys and provide only partial answers.

Interpretations of magnetic surveys (Girdler, 1970b; Kabbani, 1970; Drake and Girdler, 1964; Allan, 1970) within the Red Sea provide a consistent picture. Strong magnetic anomalies associated with the axial trough have been correlated with the geomagnetic polarity history and are considered to represent a time span of approximately 4 m.y. (Vine, 1966). Displacement of the magnetic anomalies of the axial trough between latitude $19^{\circ}$ and $23^{\circ} \mathrm{N}$ suggests the presence of active transform faults (Allan, 1970). Away from the axial trough, magnetic expressions are diffuse and fail to provide clear correlations with geomagnetic polarity history. These axial trough anomalies do not extend even to the northernmost part of the Red Sea or southward into the straits of Bab el-Mandeb.

Seismic events recorded in this area since 1953 reveal a consistent but incomplete pattern related to rifting. Most of the epicenters are along the axial trough, but surprisingly few are in the northern Red Sea (Fairhead and Girdler, 1970). Most of the events appear to be shallow $(<100 \mathrm{~km})$ and related to the development of the axial trough. Epicenters within the Afar Depression are mostly along the margins of the depression, rather than in the axial part (Gouin, 1970). Fault-plane solutions in the Red Sea axial trough indicate a strike-slip motion directed NE-SW, perhaps indicative that the axial trough is offset by a transform fault. A strong recent quake (March, 1969) in the northern Red Sea, at the opening of the Gulf of Suez, 
provided additional information on tectonic movements in this area (Ben-Menahem and Aboodi, 1971). The tectonic solution shows normal sinistral motion with dip-slip and strike-slip components and a trend of motion $10^{\circ} \mathrm{NE}$ at a depth of $10 \mathrm{~km}$.

The Red Sea area appears to be in isostatic equilibrium, according to Girdler (1969). Positive Bouguer anomalies, some as high at $140 \mathrm{mgal}$, have been detected in the central part of the axial trough. However, negative gravity anomalies in the Gulf of Aqaba may result from active left-lateral shear (Allan, 1970). The Afar Depression shows Bouguer gravity values that are generally negative and apparently related to elevation (Gouin, 1970). Positive gravity anomalies are present over volcanic centers and along the coast NE and parallel to the Danakil horst, but they are not nearly as strong as those observed over the axial trough of the Red Sea. Thick accumulations of dense oceanic crust appear therefore to be restricted to the Red Sea axial trough.

Interpretations of seismic velocities measured within the Red Sea are numerous, but controversy exists regarding the deep structures (Knott et al., 1966; Davies and Tramontini, 1970; Girdler, 1969). In the axial trough at depths of less than $5 \mathrm{~km}$ below the surface, velocities are from 6.6 to 7.0 $\mathrm{km} / \mathrm{sec}$, and it is generally agreed that the material at these depths is new oceanic crust. Other seismic traverses along the Red Sea shelf show a sedimentary cover 2 to $5 \mathrm{~km}$ thick (3.5 to $4.5 \mathrm{~km} / \mathrm{sec}$ ), consisting of a mixture of evaporites, clastics, and volcanics. The controversy centers on the nature of the material below the sedimentary cover. Davies and Tramontini (1970), surveying a $1^{\nu}$ section on the east shelf between latitude $22^{\circ}$ and $23^{\circ} \mathrm{N}$, measured velocities of $6.6 \mathrm{~km} / \mathrm{sec}$ at average depths of $4.6 \mathrm{~km}$ and concluded that this material was also oceanic crust similar to that in the axial trough; however, they may have transected one of the many greenstone belts within the Precambrian, which could also account for such high velocities. Others have measured velocities of from 5.84 to $6.97 \mathrm{~km} / \mathrm{sec}$ (average $6.1 \mathrm{~km} / \mathrm{sec}$ ) around the margins of the Red Sea and interpreted them as representing Precambrian basement (Girdler, 1969; Knott et al., 1966). Gravity measurements appear to support this interpretation, not the other.

Continuous seismic profiles reveal a strong reflector at depths from 0 to 500 meters in the marginal parts of the Red Sea, but not in the axial trough (Phillips and Ross, 1970; Knott et al., 1966). This reflector is now interpreted as the top of the evaporite section, commonly correlated with the Miocene-Pliocene boundary.

Very high values of heat flow have been measured in the axial trough of the Red Sea. Plotted as a function of closeness to the axis, heat flow increases from $\sim 3.0 \mu \mathrm{cal}$ $\mathrm{cm}^{-2} \mathrm{sec}^{-1}$ at the margins to $\sim 79 \mu \mathrm{cal} \mathrm{cm}^{-2} \mathrm{sec}^{-1}$ in the axial trough (Girdler, 1970a). Formation of new basaltic crust along the axial trough presumably provides the energy for the high heat flow. Heat flow in the entire Red Sea area, however, appears to be high, with values of 2.7 to $3.0 \mu \mathrm{cal}$ $\mathrm{cm}^{-2} \mathrm{sec}^{-1}$ along the margins and geothermal gradients of $40^{\circ} \mathrm{C} / \mathrm{km}$ and probably higher. Hot springs are common along the east margin hinge line of the Red Sea and in the Afar Depression.

\section{SUMMARY}

Formation of the Red Sea and its surrounding features is the result of many interrelated events. The fact that Red Sea structures are now an integral part of the world plate-tectonic system has obscured its earlier geologic development. Time of origin is obscure, but all evidence points toward the early Tertiary.

Late Eocene and early Oligocene thinning of the earth's crust produced the Ethiopian and Arabian swells, with the proto-Red Sea depression separating them. Vast outpourings of alkali olivine basalts formed thick Oligocene plateaus along the crests of these swells. Monoclinal flexures along the east margin related to the downwarping of the Red Sea produced a fractured hinge line that filled with differentiating tholeiitic gabbros and diabase dike swarms. These early Miocene dike swarms ( 22 m.y.) might suggest rifting in the Red Sea depression at this time, but the geologic situation clearly shows that they developed in the fractured hinge line of a monoclinal warp. Therefore, there is no compelling evidence of steady-state rifting prior to the Pliocene. Invasion of the Mediterranean seas southward into a closed depression provided conditions under which a thick $(2-5 \mathrm{~km})$ evaporite-clastic series could form. The continued development of the evaporite section during the Miocene is further evidence against large-scale opening of the Red Sea at this time even though continued subsidence is inferred with possible minor extension. Interfingering with the evaporites along the margins of the sea are thick $(2-3 \mathrm{~km})$ clastic sequences produced by erosion of the Arabian-Ethiopian swells. Continued uplift in the Miocene produced block faulting in the Afar Depression in Ethiopia, while the east margin of the Red Sea was marked by the continued depression of the marginal sediments. Erosional retreat of the edges of the Arabian and Ethiopian swells produced the present scarps. Northward the grabens of the Gulfs of Suez and Aqaba, formed by Miocene normal and wrench faulting, extended southward into the Red Sea depression. Localized Miocene basalt lavas within the Red Sea depression interlayered with the evaporites and clastics indicate localized magma generation, rather than Miocene sea-floor spreading. Seismic velocities indicate that much of the material underlying the thick Miocene evaporite-clastic sequence could be Precambrian crust rather than oceanic crust generated at the axial trough during Miocene times.

Sometime during the early Pliocene the Red Sea became part of the world rift system. Apparently Arabia broke away from Africa, opening the straits of Bab el-Mandeb and allowing the Indian Ocean to enter the Red Sea depression from the south. The unconformity between the evaporite section and the overlying marine oozes, widespread throughout the Red Sea, marks the beginning of drift. Axial rifting in the main trough gave rise to new oceanic crust consisting of subalkaline basalts, gabbros, and diabases. The strong positive Bouguer gravity anomalies and seismic velocities of 6.6 to $7.0 \mathrm{~km} / \mathrm{sec}$ within the present axial trough show that from the Pliocene to the present the trough has formed owing to volcanic activity along the active spreading center. Contemporaneous with rifting, apparent continued uplift along the Yemen-Arabian swell 
gave rise to outpourings of alkali olivine basalt. Although volcanic events within the Afar Depression coincide with the development of the Red Sea, the volcanic rocks include large amounts of silicic eruptives and differentiated basalts. Vertical faults in the Afar Depression remain active, but rifting and the development of oceanic crust similar to the Red Sea axial trough have not been demonstrated. The negative Bouguer gravity anomalies across the Danakil Depression, combined with the spectrum of differentiated lavas, seem to suggest that the Afar Depression is the northern termination of the East African continental rift system rather than a continuation of the oceanic rifts.

Present-day seismic activity is concentrated in the axial trough of the Red Sea, and fault-plane solutions suggest strike-slip movement along transform faults in a northeast direction for the Arabian plate. Within the Afar Depression the earthquake epicenters are concentrated along the marginal block faults, but insufficient fault-plane solutions prevent statements regarding motions.

The combined geophysical and geological data demonstrate that the Red Sea axial trough is a rift in which new crust is forming. This rifting appears to have begun sometime in the Pliocene. Other features of the Red Sea originated early in the Tertiary and cannot be tied directly to the world rift system as it is visualized today. A number of outstanding problems remain in this fascinating area. When did the actual Red Sea depression form? After the swells developed or contemporaneous with them? Are the marginal parts of the Red Sea underlain by continental Precambrian crust or by oceanic crust developed during the Miocene? Can the volcanic products be related to the megatectonics of the area? When did the separation of Arabia from Africa begin? Although in this summary some of these questions appear to be answered, the geologic and geophysical evidence is too sparse to be convincing. Future efforts of research in this area are important to the development of natural resources and to the documentation of a newly formed and active rift in the earth's crust.

\section{ACKNOWLEDGMENTS}

Work on which some of this paper is based was carried on while the author was a member of a U.S.G.S. project in Saudi Arabia, which operates under a work agreement funded by the Saudi Arabian Government. Permission to publish this data is approved by the Deputy Minister, Directorate General for Mineral Resources, Saudi Arabia. Dr. D. A. Ross of the Woods Hole Oceanographic Institute provided new information on the Red Sea, and his encouragement in this work is appreciated. Dr. A. S. Laughton allowed the use of his Red Sea bathymetric chart as the base for the geologic map, and Dr. R. Whitmarsh reviewed an early draft; both are from the National Institute of Oceanography, Great Britain. Dr. G. Brown, U.S. Geological Survey, provided the author with considerable information on the geology of this area, and his help in the preparation of the map was invaluable. The use of information from the Mobil Oil Co. has been helpful in the geologic synthesis of the area. We are indebted to Mr. Edward Blanton of Sun Oil Co. for providing information on the exploratory wells Badr No. 1 and Ghawwas No. 1. Dr. R. W. Girdler, University of Newcastle upon Tyne, provided the author with a continuous geophysical perspective during the preparation of this paper, and his interest is acknowledged.

\section{REFERENCES}

Ahmed, S. S., 1972, Geology and petroleum prospects in eastern Red Sea: Am. Assoc. Petrol. Geol. Bull., v. 56, p. 707-719.

Allan, T. D., 1970. Magnetic and gravity fields over the Red Sea: Phil. Trans. Roy. Soc. Lond. A., v. 267, p. 153-180.

Baker, B. H., Mohr, P. A., and Williams, L. A. J., 1972. Geology of the Eastern Rift System of Africa: Geol. Soc. Am. Spec. Paper 136.

Bannert, D., Brinckmann, J., Kading, K-ch, Knetsch, G., Kursten, M., and Mayrhofer, H., 1970. Sur Geologie der Danakil Senke: Geol. Rundschau, v. 59, p. 409-443.

Barberi, F., Borsi, S., Ferrara, G., Marinelli, G., Santacroce, R., Tazieff, H., and Varet, J., 1972. Evolution of the Danakil Depression (Afar, Ethiopia) in light of radiometric age determinations: J. Geol. v. 80, p. 720 .

Ben-Manahem, A. and Aboodi, E., 1971. Tectonic patterns in the northern Red Sea region: J. Geophys. Res., v. 76, p. 2674-2689.

Beydoun, Z. R., 1964. The stratigraphy and structure of the eastern Aden Protectorate: British Overseas Geol. Min. Resources Supp. Ser. Bull. Supp. No. 5.

Brown, G. F., 1970. Eastern margin of the Red Sea and coastal structures in Saudi Arabia: Phil. Trans. Roy. Soc. Lond., A., v. 267, p. 75-87.

1971. Tectonic map of the Arabian Peninsula: U. S. Geol. Surv. Saudi Arabian Proj. Rep. 134.

Brown, G. F. and Coleman, R. G., 1972. The tectonic framework of the Arabian Peninsula: Intern. Geol. Congr., 24th Proc., Montreal, Sec. 3.

Brown, G. F. and Jackson, R. O., 1960. The Arabian Shield: Intern. Geol. Congr., 21 st Proc., Copenhagen, Sec. 9 , p. 69-77.

Carella, R. and Scarpa, N., 1962, Geological results of exploration in Sudan by A.G.I.P. Mineraria Ltd.: Arab Petrol. Congr., 4th Beirut.

Chase, R. L., 1969. Basalt from the axial trough of the Red Sea. In Degens, E. T., and Ross, D. A. (eds.), Hot brines and recent heavy metal deposits in the Red Sea: New York (Springer-Verlag), p.122-128.

Choubert, G., 1968. International tectonic map of Africa, 1:5,000,000: UNESCO, Paris.

Coleman, R. G. and Brown, G. F., 1971. Volcanism in southwest Saudi Arabia: Geol. Soc. Am. Abstr. with Programs, v. 3, p. 529.

Davies, D and Tramontini, C., 1970. The deep structure of the Red Sea: Phil. Trans. Roy. Soc. Lond., A., v. 267, p. 181-189.

Drake, C. L. and Girdler, R. W., 1964. A geophysical study of the Red Sea: Roy. Astron. Soc. Geophys. J., v. 8, p. 473-495.

Fairhead, J. D. and Girdler, R. W., 1970. The seismicity of the Red Sea, Gulf of Aden and Afar triangle: Phil. Trans. Roy. Soc. Lond., A., v. 267, p. 49-74.

Frazier, S. B., 1970. Adjacent structures of Ethiopia: that portion of the Red Sea Coast including Dahlak Kebir Island and the Gulf of Zula: Phil. Trans. Roy. Soc. Lond., A., v. 267, p. 131-141.

Gass, I. G., 1970. The evolution of volcanism in the junction area of the Red Sea, Gulf of Aden and Ethiopian rifts: Phil. Trans. Roy. Soc. Lond., A., v. 267, p. 369-381.

Gass, I. G. and Gibson, I. L., 1969. Structural evolution of the rift zones in the Middle East: Nature, v. 221, p. $926-930$.

Gass, I. G., Mallick, I. J., and Cox, K. G., 1965. Royal Society volcanological expedition to the south Arabian Federation and the Red Sea: Nature, v. 205, p. 952-955. 
Geukens, F., 1966. Geology of the Arabian Peninsula, Yemen: U. S. Geol. Survey Prof. Paper 560-B.

Gillmann, M., 1968. Preliminary results of a geological and geophysical reconnaissance of the Gizan coastal plain in Saudi Arabia: AIME Symp. Khahran, Saudi Arabia, p. 198-208.

Girdler, R. W., 1969. The Red Sea - a geophysical background. In Degens, E. T. and Ross, D. A. (eds.), Hot brines and recent heavy metal deposits in the Red Sea: New York (Springer-Verlag), p. 38-58.

1970a. A review of Red Sea heat flow: Phil. Trans. Roy. Soc. Lond., A., v. 267, p. 191-203.

Girdler, R. W., 1970b. An aeromagnetic survey of the junction of the Red Sea, Gulf of Aden and Ethiopian rifts - A preliminary report: Phil. Trans. Roy. Soc. Lond., A., v. 267 , p. $359-368$.

Gouin, P., 1970. Seismic and gravity data from Afar in relation to surrounding areas: Phil. Trans. Roy. Soc. Lond., A., v. 267, p. 339-358.

Greenwood, W. R., 1972. The Hail Arch: a key to the Arabian shield during evolution of the Red Sea Rift: Geol. Soc. Am. Absts. with Programs, v. 4, p. 520.

Heybroek, F., 1965. The Red Sea evaporite basin. In Salt basins around Africa: London (Inst. Petroleum), p. $17-40$.

Holmes, A., 1965. Principles of physical geology: London (Nelson),

Holwerda, J. G. and Hutchinson, R. W., 1968. Potash-bearing evaporites in the Danakil area, Ethiopia: Econ Geol., v. 63, p. 124-150.

Hutchinson, R. W. and Engels, G. G., 1970. Tectonic significance of regional geology and evaporite lithofacies in northeastern Ethiopia: Phil. Trans. Roy. Soc. Lond., A., v. 267, p. 313-329.

Kabbani, F. K., 1970. Geophysical and structural aspects of the central Red Sea rift valley: Phil. Trans. Roy. Soc. Lond., A., v. 267, p. 89-97.

Karpoff, R., 1957. Sur L'esistence du Maestrichtien au nord de Djeddah (Arabie Sedouite): Compt. Rend. Acad. Sci., v. 245 , p. $1322-1324$.

Knott, S. T., Bunce, E. T., and Chase, R. L., 1966. Red Sea seismic reflection studies. In The world rift system: Canada Geol. Surv. Paper 66-14, p. 33-61.

Laughton, A. S., 1970. A new bathymetric chart of the Red Sea: Phil. Trans. Roy. Soc. Lond., A., v. 267, p. 21-22.

Lowell, J. D. and Genik, G. J., 1972. Sea-floor spreading and structural evolution of southern Red Sea: Am. Assoc. Petrol. Geol. Bull., v. 56, p. 247-259.

McKenzie, D. P., Davies, D., and Molnar, P., 1970. Plate tectonics of the Red Sea and East Africa: Nature, v. 226, p. 243-248.

MacFadyen, W. A., 1930. The geology of the Farsan Islands, Gizan, and Kamaran Island, Red Sea, Part I General geology: Geol. Mag., v. 67, p. 310-315.
1932. On the volcanic Zebayir Islands, Red Sea: Geol. Mag., v. 69, p. 63-66.

Mohr, P. A., 1962. The geology of Ethiopia: Univ. College of Addis Ababa Press.

1971. Ethiopian rift and plateaus: some volcanic petrochemical differences: J. Geophys. Res., v. 76, p. 1967-1984.

Montanaro, G. E., 1941. Foraminiferi, posizione stratigrafica e facies di un calcare a "operculina" dei Colli di Ebud (Sahel Eritreo): Palaeontogr. Ital., v. 40 (n.s. 10), p. 67-75.

Phillips, J. D. and Ross, D. A., 1970. Continuous seismic reflexion profiles in the Red Sea: Phil. Trans. Roy. Soc. Lond., A., v. 267, p. 143-152.

Picard, L., 1970. On Afro-Arabian graben tectonics: Geol. Rundschau, v. 59, p. 337-381.

Ross, D. A., Whitmarsh, R. B., Ali, S., Boudeaux, J. E., Coleman, R. G., Fleischer, R. L., Girdler, R., Manheim, F., Matter, A., Nigrini, C., Stoffers, P., and Supko, P., 1972. Deep sea drilling project in the Red Sea: Geotimes, v. 17, p. 24-26.

Said, R., 1962. The geology of Egypt: Elsevier Pub. Col, 377 p.

Schurmann, H. M. E., 1966. The Precambrian along the Gulf of Suez and the northern part of the Red Sea: Leiden (Brill).

Sestini, J., 1965. Cenozoic stratigraphy and depositional history, Red Sea coast, Sudan: Am. Assoc. Petrol. Geol. Bull., v. 49, p. 1453-1472.

Shanti, M. S., 1966. Oolitic iron ore deposits in Wadi Fatima between Jeddah and Mecca, Saudi Arabia: Saudi Arabia Min. Res. Bull. 2, Jeddah, Saudi Arabia.

Swartz, D. H. and Arden, D. D., Jr., 1960. Geologic history of Red Sea area: Am. Assoc. Petrol. Geol. Bull., v. 44, p. 1621-1637.

Tazieff, H., Varet, J., Barberi, F., and Giglia, G., 1972. Tectonic significance of the Afar (or Danakil) depression: Nature, v. 235, p. 144-147.

Tromp, S. W., 1950. The age and origin of the Red Sea graben: Geol. Mag., v. 37, p. 385-392.

U. S. Geological Survey, 1963. Topographic map-Arabian Peninsula 1:2,000,000: U. S. Geol. Surv. Misc. Geol. Inv. Map I-270, B-2.

Vine, F. J., 1966. Spreading of the ocean floor: New evidence: Science, v. 154, p. 1405-1415.

Whiteman, A. J., 1968. Formation of the Red Sea depression: Geol. Mag., v. 105, p. 231-246.

1970. The existence of transform faults in the Red Sea depression: Phil. Trans. Roy. Soc. Lond., A., v. 267 , p. $407-408$.

, 1971. The geology of the Sudan Republic: Oxford (Clarendon Press). 